\title{
PENERAPAN MODEL PEMBELAJARAN DISCOVERY DALAM PEMBELAJARAN IPS PADA SISWA KELAS IXB MTS NEGERI 5 KUNINGAN
}

\author{
Teti Sutriati
}

MTs Negeri 5 Kuningan, Indonesia

tetisutriati@gmail.com

\begin{abstract}
This research is motivated by the low student learning outcomes in social studies subjects. Discovery learning model was chosen as a solution to these problems, this is because the discovery model provides an opportunity for students to find their own knowledge. This study aims to improve student learning outcomes in social studies subjects by using the Discovery learning model. The research method used is classroom action research with Kemmis and Mc Taggart designs. The research subjects were students of IXB grade at MTs Negeri Kuningan in 2019/2020 school year. To collect data, the instrument used is a matter of description and observation sheet. From the results of the study obtained an average student learning outcomes that increase in each cycle of classroom action research conducted. Thus it can be concluded the use of the Discovery Approach Model in social studies learning can improve student learning outcomes. Keywords: Discovery Model, Social Studies Learning, Learning Outcomes.
\end{abstract}

ABSTRAK

Penelitian ini dilatarbelakangi rendahnya hasil belajar siswa pada mata pelajaran IPS. Model pembelajaran Discovery dipilih sebagai solusi atas permasalahan tersebut, hal ini karena model discovery memberikan kesempatan pada siswa untuk menemukan pengetahuannya sendiri. Penelitian ini bertujuan untuk meningkatkan hasil belajar siswa pada mata pelajaran IPS dengan menggunakan Model pembelajaran Discovery. Metode penelitian yang digunakan yaitu penelitian tindakan kelas dengan desain Kemmis dan Mc Taggart. Subyek penelitian adalah siswa kelas IXB MTs Negeri Kuningan pada tahun pelajaran 2019/2020. Untuk mengumpulkan data, instrument yang digunakan adalah soal uraian dan lembar observasi. Dari hasil penelitian diperoleh rata-rata hasil belajar siswa yang meningkat pada setiap siklus penelitian tindakan kelas yang dilaksanakan. Dengan demikian dapat kesimpulan penggunaan Model Pendekatan Discovery dalam pembelajaran IPS dapat meningkatkan hasil belajar siswa.

Kata Kunci: Model Discovery, Pembelajaran IPS, Hasil belajar.

Submitted December 1, 2019 | Revised December 6, 2019 | Accepted December 11, 2019

\section{Pendahuluan}

IPS merupakan salah satu disiplin ilmu yang masuk pada kurikulum di setiap jenjang pendidikan, termasuk pada sekolah lanjutan tingkat pertama. IPS memiliki tujuan untuk mengembangkan potensi peserta didik atau siswa agar peka terhadap masalah sosial yang terjadi di masyarakat, memiliki sikap mental positif terhadap perbaikan segala ketimpangan yang terjadi, dan terampil mengatasi setiap masalah yang terjadi sehari-hari baik yang menimpa dirinya sendiri maupun yang menimpa masyarakat. Somantri (Sapriya: 2008) menyatakan IPS adalah penyederhanaan atau disiplin ilmu ilmu sosial humaniora serta kegiatan dasar manusia yang diorganisasikan dan disajikan secara ilmiah dan pedagogis/psikologis untuk tujuan pendidikan. Adapun yang menjadi ruang lingkup pelajaran IPS menurut Taneo (2009) adalah manusia sebagai anggota masyarakat atau manusia dalam konteks sosial.

Pentingnya manusia mempelajari ilmu pengetahuan sosial sebagai bekal bagi dirinya agar bisa bermanfaat bagi dirinya dan masyarakat luas dan bisa menerapkan ilmunya langsung ke masyarakat melalui tindakan-tindakan nyata yang merupakan hasil dari pembelajaran yang ia 
dapatkan dan memiliki nila guna serta bagus di masyarakat. Pendidikan IPS pada hakekatnya berfungsi untuk membantu perkembangan peserta didik memiliki konsep diri yang baik, membantu pengenalan dan apresiasi tentang masyarakat global dan komposisi budaya, sosialisasi proses sosial, ekonomi, politik, membantu siswa untuk mengetahui waktu lampau dan sekarang sebagai dasar untuk mengambil keputusan, mengembangkan kemampuan untuk memecahkan masalah dan keterampilan menilai, membantu perkembangan peserta didik untuk berpartisipasi secara aktif dalam kehidupan masyarakat (Skeel, 1995:11).

Tujuan pembelajaran IPS tidak hanya menekankan pada aspek pengetahuan saja, melainkan juga pembinaan peserta didik untuk mengembangkan dan menerapkan nilai-nilai pengetahuan tersebut di tengah masyarakat. Nilai-nilai tersebut misalnya tenggang rasa dan tepo sliro, kepedulian terhadap sesama dan lingkungan, disiplin, ketaatan, keteraturan, etos kerja, dan lain-lain. Selain itu tujuan pembelajaran IPS adalah untuk mengembangkan potensi peserta didik atau siswa agar peka terhadap masalah sosial yang terjadi di masyarakat, memiliki sikap mental positif terhadap perbaikan segala ketimpangan yang terjadi, dan terampil mengatasi setiap masalah yang terjadi sehari-hari baik yang menimpa dirinya sendiri maupun yang menimpa masyarakat.

Pentingnya IPS bagi siswa ternyata tidak sepenuhnya dipahami siswa. Hal ini terlihat dari pembelajaran IPS yang dilaksanakan tidak menjadikan siswa aktif belajar. Hal ini berdampak pada hasil belajar siswa yang rendah. Rendahnya hasil belajar siswa pada mata pelajaran IPS juga dialami siswa kelas IXB MTs Negeri 5 Kuningan. Terbukti dari hasil ulangan pada siswa Kelas IX B MTs Negeri 5 Kuningan nilainya hanya mencapai 21,9\% (9 siswa) dari 40 siswa yang dinilai sudah memahami mata pelajaran IPS dalam materi teresebut. Kegiatan belajar mengajar yang dilakukan di MTs Negeri 5 Kuningan pada umumnya menggunakan metode ceramah. Penerapan metode ceramah dapat menimbulkan kejenuhan pada siswa, kurang merangsang partisipasi siswa sehingga proses belajar terjadi hanya satu arah. Akibatnya,pembelajaran pun kurang menarik, tidak menyenangkan, dan membuat jenuh bagi siswa. Siswa hanya menjadi penerima pasif, kurang responsif, dan ada kecenderungan untuk menolak berinteraksi dengan guru.

Dari uraian diatas jelas bahwa hasil belajar siswa pada mata pelajaran IPS masih rendah. Dibutuhkan berbagai upaya untuk meningkatkan hasil belajar siswa, salah satunya dengan menggunakan model pembelajaran yang tepat. Model pembelajaran sangat mempengaruhi aktivitas belajar siswa. Apabila guru mengajar dengan metode yang kurang baik maka akan mempengaruhi belajar siswa yang kurang baik pula. Guru yang biasa mengajar dengan metode ceramah saja, akan menjadikan siswa bosan, pasif, tidak minat belajar. Oleh karena itu guru dituntut menggunakan model pembelajaran lain atau metode-metode yang baru disesuaikan dengan kondisi dan situasi belajar agar motivasi dan minat siswa untuk belajar tetap tinggi dan semangat, yang pada akhirnya tujuan belajar dapat tercapai dengan efektif dan efisien, cepat dan tepat. Salah satu model yang sesuai dengan kriteria di atas adalah model pembelajaran Discovery.

Model pembelajaran discovery adalah model mengajar yang mengatur pengajaran sedemikian rupa sehingga anak memperoleh pengetahuan yang sebelumnya belum diketahuinya itu tidak melalui pemberitahuan, sebagian atau seluruhnya ditemukan sendiri (Handayani, 2015). Menurut Effendi, Discovery learning merupakan suatu pembelajaran yang melibatkan peserta didik dalam pemecahan masalah untuk pengembangan pengetahuan dan ketrampilan (Yuliana, 2018). Discovery learning adalah suatu model untuk mengembangkan cara belajar aktif dengan 
menemukan sendiri, menyelidiki sendiri, maka hasil yang diperoleh akan setia dan tahan lama dalam ingatan. Melalui belajar penemuan, siswa juga bisa belajar berpikir analisis dan mencoba memecahkan sendiri masalah yang dihadapi (Hosnan, 2014:282). Menurut Kurniasih, dkk (2014:64), Model discovery learning adalah proses pembelajaran yang terjadi bila pelajaran tidak disajikan dengan pelajaran dalam bentuk finalnya,tetapi diharapkan siswa mengorganisasikan sendiri. Discovery adalah menemukan konsep melalui serangkaian data atau informasi yang diperoleh melalui pengamatan atau percobaan. Menurut Ruseffendi (2006:329), metode Discovery Learning adalah metode mengajar yang mengatur pengajaran sedemikian rupa sehingga anak memperoleh pengetahuan yang belum diketahuinya itu tidak melalui pemberitahuan, sebagian atau seluruhnya ditemukan sendiri.

Model Discovery memiliki beberapa keunggulan antara lain : siswa aktif dalam kegiatan belajar, sebab ia berpikir dan menggunakan kemampuan untuk menemukan hasil akhir; siswa memahami benar bahan pelajaran, sebab mengalami sendiri proses menemukannya. Sesuatu yang diperoleh dengan cara ini lebih lama diingat; menemukan sendiri menimbulkan rasa puas. Kepuasan batin ini mendorong ingin melakukan penemuan lagi sehingga minat belajarnya meningkat; dan siswa yang memperoleh pengetahuan dengan metode penemuan akan lebih mampu mentransfer pengetahuannya ke berbagai konteks (Suherman, 2001: 179). Bentuk metode pembelajaran Discovery Learning dapat dilaksanakan dalam komunikasi satu arah atau komunikasi dua arah bergantung pada besarnya kelas (Hamalik, 2009:187). Pendekatan satu arah berdasarkan penyajian satu arah yang dilakukan guru. Struktur penyajiannya dalam bentuk usaha merangsang siswa melakukan proses discovery di depan kelas. Guru mengajukan suatu masalah, dan kemudian memecahkan masalah tersebut melalui langkah-langkah discovery. Sistem dua arah melibatkan siswa dalam menjawab pertanyaanpertanyaan guru. Siswa melakukan discovery, sedangkan guru membimbing mereka ke arah yang tepat atau benar. Menurut Petrayasa, melalui model discovery learning siswa menjadi lebih dekat dengan apa yang menjadi sumber belajarnya, rasa percaya diri siswa akan meningkat karena dia merasa apa yang telah dipahaminya ditemukan oleh dirinya sendiri, kerjasama dengan temannya pun akan meningkat, serta tentunya menambah pengalaman siswa (Rosarina, 2016).

\section{Metode Penelitian}

Metode yang digunakan dalam penelitian ini merupakan Penelitian Tindakan kelas (PTK). PTK merupakan suatu penelitian yang mengangkat masalah-masalah aktual yang dihadapi oleh guru di lapangan. PTK adalah proses pengkajian masalah pembelajaran di dalam kelas melalui refleksi diri dalam upaya untuk memecahkan masalah tersebut dengan cara melakukan tindakan yang terencana dalam situasi nyata serta menganalisis setiap pengaruh dari perlakuan tersebut (Sanjaya, 2011: 26). Pendapat tersebut sesuai pendapat yang disampaikan oleh Kasbolah (2001: 15), bahwa Penelitian Tindakan Kelas merupakan penelitian tindakan dalam bidang pendidikan yang dilaksananakan dalam kawasan kelas dengan tujuan untuk memperbaiki dan atau meningkatkan kualitas pembelajaran.

Banyak model Penelitian Tindakan Kelas yang dapat diterapkan, tetapi dalam penelitian ini menggunakan model Kemmis dan McTaggart di mana dalam perencanaannya menggunakan 
siklus sistem spiral yang di dalamnya terdiri dari empat komponen, yaitu rencana, tindakan dan observasi serta refleksi (Sujati, 2000: 23).

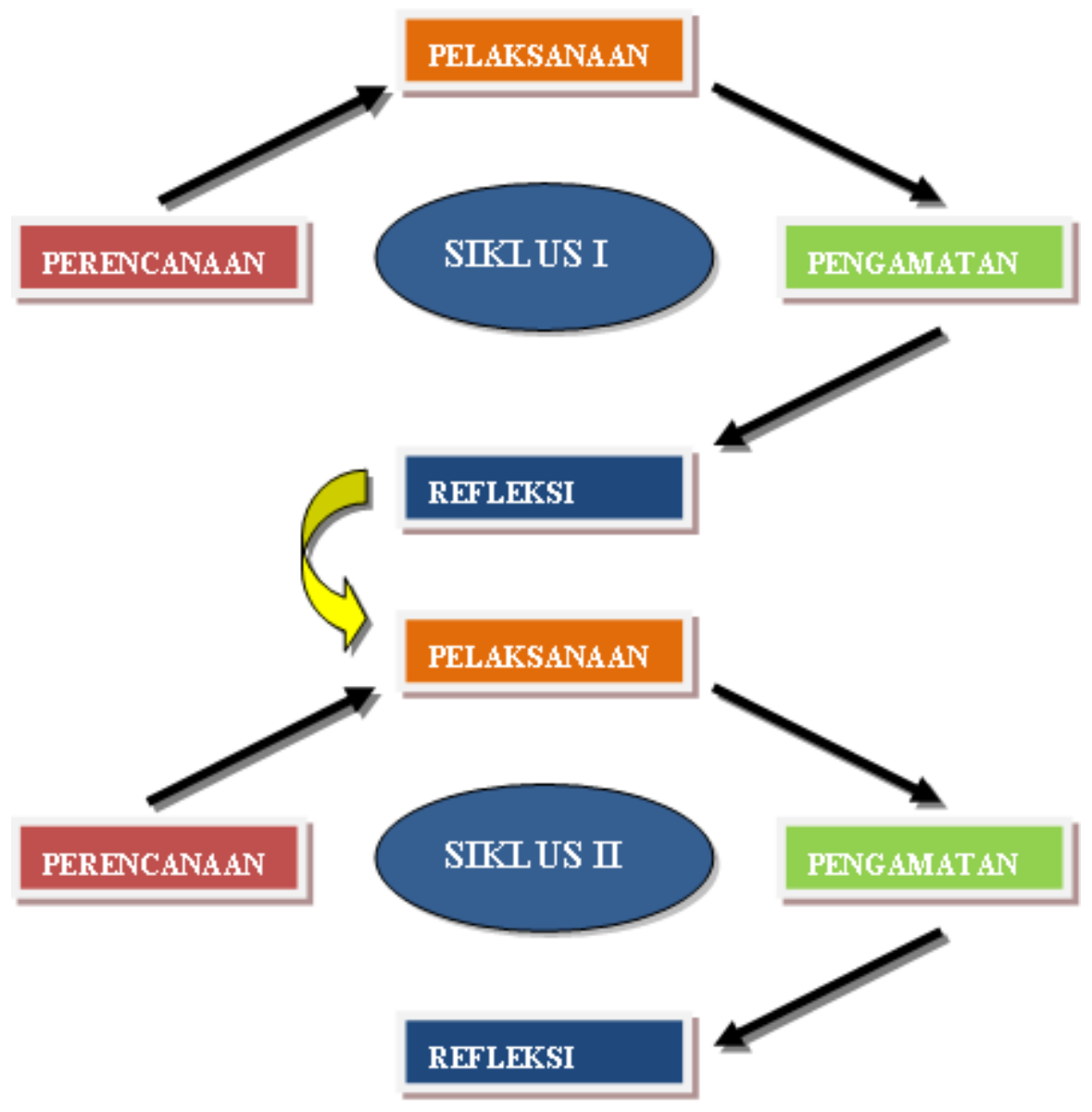

Gambar 1. Model kemmis dan Mc Taggart (Sujati, 2000: 23). berikut:

Dari gambar 1 di atas maka, penelitian tindakan yang akan dilakukan dapat diuraikan sebagai 1. Perencanaan (Plan)

Melakukan observasi terhadap situasi atau kemampuan motorik halus anak sebelum dilakukan tindakan, membuat Rencana Kegiatan Harian terlebih dahulu dengan berdiskusi bersama guru kelas (kolaborator), membuat media yang digunakan untuk kegiatan pembelajaran serta mempersiapkan peralatan yang dibutuhkan bersama kolaborator, mempersiapkan lembar observasi yang digunakan untuk mengambil data serta melakukan penilaian dan evaluasi, melakukan setting atau penataan ruang kelas yang mendukung kegiatan pembelajaran.

2. Pelaksanaan (Act) dan Observasi (Observe)

Pelaksanaan dilakukan sesuai dengan perencanaan yang telah dibuat guru kelas dengan peneliti. Pelaksanaan penelitan dilakukan secara fleksibel yaitu bisa berubah sesuai dengan situasi dan kondisi yang ada di lapangan. Guru kelas sebagai kolaborator melaksanakan tindakan yang 
sudah direncanakan sesuai RKH sedangkan peneliti mengamati proses pembelajaran yang berlangsung.

3. Refleksi (Reflect)

Refleksi dilakukan pada setiap akhir siklus untuk mengetahui apakah kegiatan mewarnai yang diberikan sudah sesuai harapan atau belum serta digunakan peneliti dan kolaborator dalam melakukan evaluasi tentang perlu tidaknya melakukan siklus selanjutnya. Selain itu, melalui refleksi dapat melakukan analisis data pada lembar observasi yang telah diisi oleh peneliti dan kolaborator serta melakukan penilaian untuk menyusun rencana perbaikan yang akan dilakukan (Arikunto, 2010).

Subjek penelitian tindakan kelas ini adalah siswa Kelas IX B MTs Negeri 5 Kuningan Kabupaten Kuningan tahun ajaran 2019/2020 berjumlah 38 siswa. Subyek penelitian ini diambil secara keseluruhan, sebagai obyek penelitian karena asumsikan karakteristik dan kemampuan dianggap sama.

Prosedur penelitian tindakan kelas dilakukan dengan dua siklus, dan tiap siklus dilaksanakan sesuai dengan perubahan yang dicapai dan desain faktor yang diteliti. Untuk mengetahui efektifitas pembelajaran di Kelas IX B MTs Negeri 5 Kuningan Kabupaten Kuningan dilakukan observasi terhadap kegiatan pembelajaran yang dilakukan oleh guru, dan wawancara baik dengan guru maupun siswa. Melalui kegiatan ini dapat dilakukan musyawarah antara guru dengan observer untuk menetapkan tindakan yang paling tepat dalam rangka meningkatkan efektifitas pembelajaran di kelas IX B. Hasil wawancara guru kelas, langkah yang paling tepat adalah meningkatkan aktivitas dan peran serta siswa dalam proses pembelajaran tersebut dengan melatih dan mengembangkan keterampilan intelektual siswa.

Instrumen penelitian tindakan kelas ini adalah Tes tertulis dan observasi. Tes tertulis digunakan untuk mengumpulkan data tentang kemampuan siswa dalam menguasai materi yang diajarkan. Dan test tertulis ini dirancang oleh peneliti sesuai dengan tujuan yang telah tertuang di dalam kisi-kisi soal. Teknik observasi untuk memperoleh data tentang pemahaman urutan perilaku siswa dengan lengkap meliputi Suasana kelas dan Perilaku masing-masing saat memngikuti pembelajaran di dalam kelas.

Adapun yang menjadi indikator keberhasilan penelitian tindakan kelas ini adalah jika Penguasan materi "Ketergantungan antar ruang berdasarkan konsep ekonomi" pada siswa kelas IX B MTs Negeri 5 Kuningan Kabupaten Kuningan pada akhir penelitian ini meningkat hingga mencapai $90 \%$, berarti siswa telah mencapai nilai di atas batas ketuntasan minimal. Penerapan teknik pembelajaran dengan Model Pendekatan Discovery dalam proses pembelajaran Sejarah pada materi "Ketergantungan antar ruang berdasarkan konsep ekonomi", yang ditandai dengan meningkatnya hasil belajar atau nilai yang diperoleh masing-masing siswa, berarti Model pembelajaran tersebut adalah efektif untuk diterapkan.

\section{Hasil dan Pembahasan}

Hasil yang diperoleh dalam penelitian ini diantaranya temuan kuantitatif dan temuan kualitatifdiantaranya Aktivitas siswa dalam mengikuti kegiatan pembelajaran IPS tentang "Ketergantungan antar ruang berdasarkan konsep ekonomi" yang tampak antusias mengikuti pembelajaran. Siswa yang mengajukan pertanyaan meningkat, mencapai antara $61 \%-80 \%$. 
Siswa yang bisa menjawab pertanyaan meningkat mencapai antara $61 \%$ - $80 \%$. Siswa yang menyampaikan pendapat meningkat mencapai antara $61 \%$ - $80 \%$. Siswa yang memperhatikan secara aktif meningkat mencapai antara $81 \%$ - $100 \%$. Siswa yang bekerja dan belajar secara aktif meningkat mencapai antara $81 \%-100 \%$.

Guru dalam kegiatan pembelajaran IPS menunjukkan kinerja baik sekali, dari mulai kegiatan awal, kegiatan inti, hingga kegiatan akhir pembelajaran mencapai rata-rata $90 \%$ dilaksanakan sesuai RPP. Dengan demikian, hasil pembahasan secara kuantitatif terhadap hasil pretest dan post test menunjukkan hasil rata-rata skor, Hasil awal (Pra test) menunjukkan skor rata-rata: 54,21. Hasil pada siklus I naik menjadi skor rata-rata: 67,56. Hasil pada siklus II naik menjadi skor ratarata: 80,78 .

Jika di buat grafik tentang peningkatan nilai/ skor hasil belajar dalam pembelajaran IPS tentang "Ketergantungan antar ruang berdasarkan konsep ekonomi" pada tiap siklusnya dapat dilihat melalui diagram berikut.

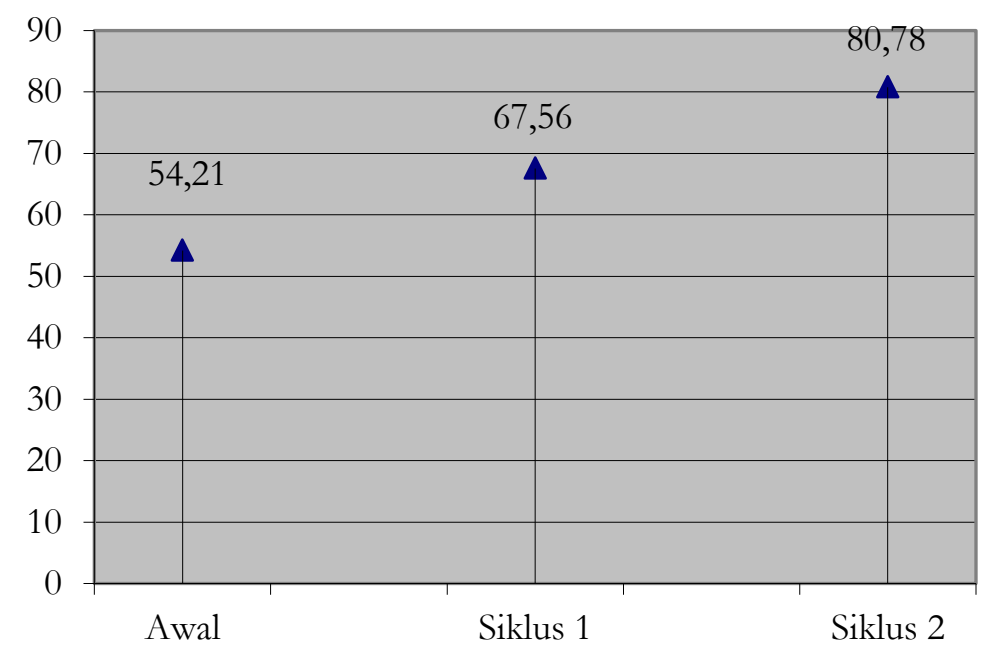

Gambar 2

Diagram Nilai Rata-rata dalam Mata Pelajaran IPS

Jika diprosentase tentang skor/ nilai hasil belajar siswa yang memperoleh nilai hasil awal (pra test) yang memperoleh 70 ke atas mencapai $24,4 \%$. Hasil pada siklus I yang memperoleh 70 ke atas mencapai 58,5\%. Hasil pad asiklus II yang memperoileh 70 ke atas mencapai 97,6 \%. Jika di buat grafik tentang prosentase peningkatan nilai/ skor hasil belajar dalam pembelajaran IPS tentang "Ketergantungan antar ruang berdasarkan konsep ekonomi" pada tiap siklusnya dapat dilihat melalui diagram berikut. 


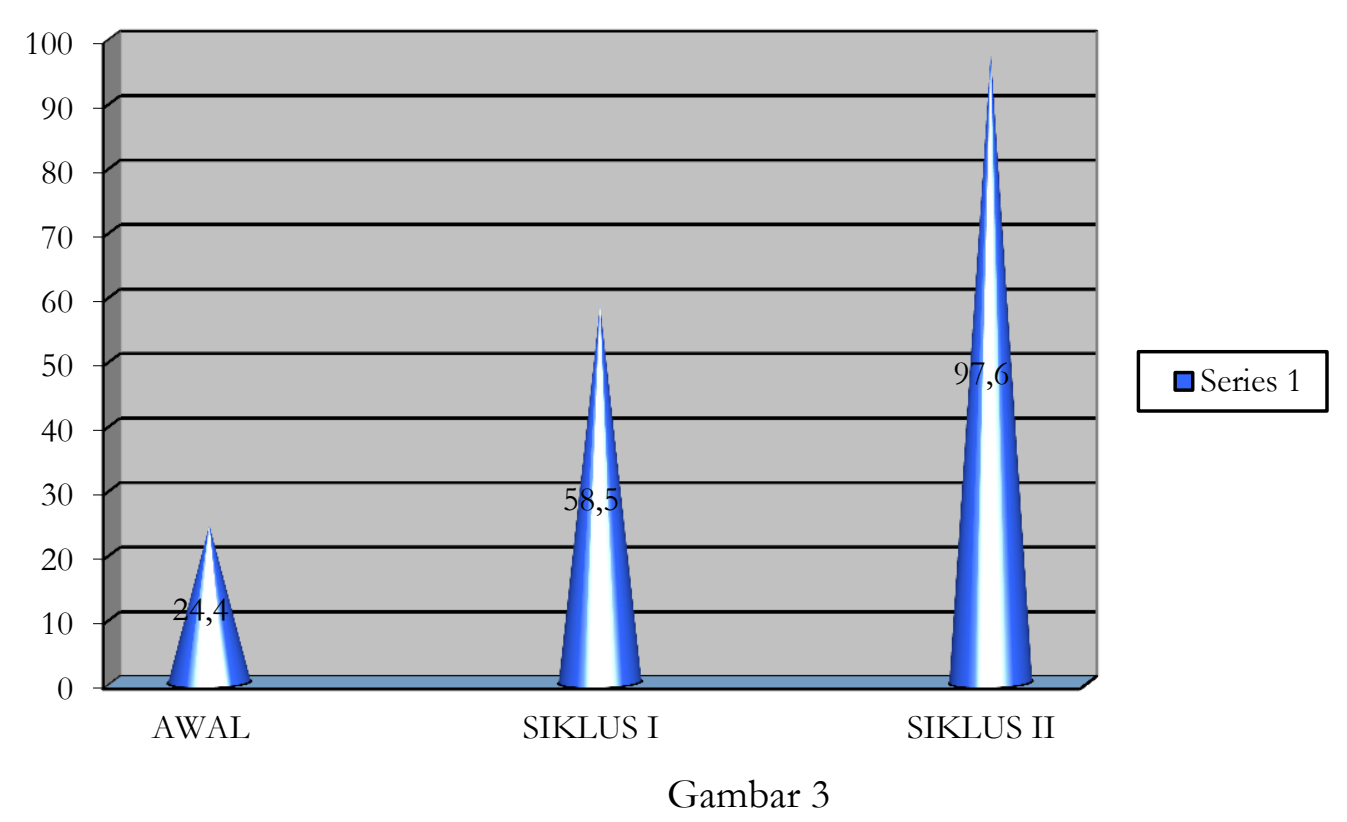

Diagram Perolehan Nilai Sama dengan 70 ke Atas dalam Mata Pelajaran IPS

Aktivitas belajar siswa dalam kegiatan pembelajaran IPS Pada siklus I menunjukkan ratarata $40 \%$ ( Cukup Baik). Pada siklus II naik, dan menunjukkan rata-rata $84 \%$ (Baik sekali). Kinerja guru dalam dalam proses pembelajaran IPS tentang "Ketergantungan antar ruang berdasarkan konsep ekonomi” Pada siklus I menunjukkan rata-rata $44 \%$ (cukup). Pada siklus II naik, dan menunjukkan rata-rata $90 \%$ (baik sekali). Berdasarkan penjelasan di atas dapat disimpulkan bahwa dengan menerapkan Model Pendekatan Disscovery hasil belajar IPS tentang "Ketergantungan antar ruang berdasarkan konsep ekonomi" di Kelas IX B MTs Negeri 5 Kuningan Kabupaten Kuningan dapat meningkat.

\section{Kesimpulan}

Berdasarkan hasil penelitian dan pembahasan, maka disimpulkan bahwa model discovery dapat meningkatkan hasil belajar IPS tentang "Ketergantungan antar ruang berdasarkan konsep ekonomi” di Kelas IX B MTs Negeri 5 Kuningan Kabupaten Kuningan. Peningkatan tersebut dapat dilihat dari adanya peningkatan persentase dari sebelum tindakan dan setelah pelaksanaan tindakan pada siklus I dan siklus II. Keberhasilan tersebut tidak terlepas dari langkah-langkah pembelajaran discovery yang memfasilitasi kesempatan kepada siswa untuk belajar secara mandiri.

\section{Daftar Pustaka}

Arikunto, S. (2010). Penelitian Tindakan Sekolah. Yogyakarta: Aditya Media

Hamalik. (2009). Pendekatan Baru Strategi Belajar mengajar Berdasarkan CBSA. Bandung: Sinar Baru Algensindo 
Handayani. (2015). Upaya Meningkatkan Hasil Belajar Ips Melalui Model Pembelajaran Discovery Siswa Kelas VIII F SMPN 2 Ngemplak Tabun Pelajaran 2014/2015. Jipsindo. 2 (2). 161-178.

Hosnan, M. (2014). Pendekatan Saintifik dan Kontekstual dalam Pembelajaran Abad 21. Bogor: Ghalia Indonesia.

Kasbolah (2001). Penelitian Tindakan Kelas. Jakarta: Bumi Aksara.

Kurniasih, Imas dan Berlin Sani. (2014). Implementasi Kurikulum 2013 Konsep dan Penerapan. Surabaya: Kata Pena.

Ruseffendi. (2006). Pengantar Kepada Membantu Guru Mengembangkan Kompetensinya dalam Pengajaran Matematika. Bandung: Tarsito.

Rosarina, dkk. (2016). Penerapan Model Discovery Learning Untuk Meningkatkan Hasil Belajar Siswa Pada Materi Perubahan Wujud Benda. Jurnal Pena Ilmiah: Vol. 1, No. 1 (2016). 371-380.

Sanjaya. (2010). Penelitian Tindakan Sekolah. Jakarta: Kencana.

Sapriya. (2008). Konsep Dasar IPS. Bandung: CV Yasindo Multi Aspek

Skeel, D. J. (1995), Elementery Social Studies : Challenges for Tomorrow's. World. Orlando, Florida

Sujati. (2000). Penelitian Tindaka Kelas. Yogyakarta. FIP. UNY.

Suherman, Erman dkk. (2001). Strategi Pembelajaran Matematika Kontemporer. Bandung: Jica.

Taneo, S. P. Dkk. (2009) Kajian IPS SD. Jakarta. Dirjaen Dikti. Depdiknas.

Yuliana, N. (2018). Penggunaan Model Pembelajaran Discovery Learning Dalam Peningkatan Hasil Belajar Siswa Di Sekolah Dasar. Jurnal Ilmiah Pendidikan dan Pembelajaran. Vol 2 (1), hal 21-28. 